\title{
Promoter (4G/5G) plasminogen activator inhibitor-1 genotype in Pima Indians: relationship to plasminogen activator inhibitor-1 levels and features of the insulin resistance syndrome
}

\author{
L.J. M cC ormack ${ }^{1}$, D.K. Nagi ${ }^{2}$, M. H. Stickland ${ }^{1}$, M. W. Mansfield ${ }^{1}$, V. M ohamed-A li ${ }^{3}$, J .S. Y udkin ${ }^{3}$, W. C. K nowler ${ }^{4}$, \\ P.J. G rant ${ }^{1}$ \\ ${ }^{1} \mathrm{U}$ nit of M olecular Vascular M edicine, R esearch School of M edicine, U niversity of L eeds, UK \\ ${ }^{2}$ E dna Coates D iabetes Centre, Pinderfields, Wakefield, U K \\ ${ }^{3}$ D epartment of M edicine, U niversity College L ondon M edical School, Whittington H ospital, L ondon, U K \\ ${ }^{4}$ National Institutes of H ealth, NIDDK, Phoenix, A rizona, U SA
}

Summary Elevated plasminogen activator inhibitor-1 may contribute to vascular disease in diabetes mellitus. Pima Indians have a low incidence of cardiovascular disease despite having a high prevalence of non-insulin-dependent diabetes mellitus (NIDDM) which in this population is not associated with elevated plasminogen activator inhibitor-1 activity. In Caucasians an insertion/deletion (4G/5G) polymorphism in the promoter region of the plasminogen activator inhibitor-1 gene that has been related to activity levels of its protein in plasma differentially binds repressor and enhancer elements. In 265 Pima Indians ( 133 diabetic, 132 non-diabetic, 129 male, 136 female, mean age 46.6 , range $34-68$ years) the promoter genotype frequencies were $23.0 \%$ for $4 \mathrm{G} / 4 \mathrm{G}$, $49.8 \%$ for $4 \mathrm{G} / 5 \mathrm{G}$ and $27.2 \%$ for $5 \mathrm{G} / 5 \mathrm{G}$ compared to $35.4 \%, 50.8 \%$ and $13.8 \%$ respectively $\left(\chi^{2}=15.3\right.$, $2 \mathrm{df}, \mathrm{p}<0.0005)$ previously reported in Caucasians with NID D M. The mean plasma activity levels in the three genotypes in the Pima Indians were 18.2, 19.1 and $18.1 \mathrm{U} / \mathrm{ml}$, respectively. Plasminogen activator inhibitor-1 activities correlated with plasma insulin $(r=0.38, p<0.0001)$, body mass index $(r=0.24$, $p<0.0001)$, and with triglyceride level $(r=0.12$, $p=0.054$ ) but there was no relationship between promoter genotype and activity. A steeper regression slope between plasminogen activator inhibitor-1 activity and triglycerides has been observed in Caucasians with the 4G /4G genotype as compared to Caucasians with the other genotypes. This was not found in the Pima population which may indicate a functional difference in this gene associated with reduced cardiovascular risk and may be involved in the lack of association of plasminogen activator inhibitor-1 levels with NIDDM in Pima Indians. [D iabetologia (1996) 39: 1512-1518]

Keywords Plasminogen activator inhibitor-1, fibrinolysis, Pima Indians, polymorphism, genetic, diabetes mellitus, non-insulin-dependent.
In Caucasians, the two to threefold increase in cardiovascular disease seen in subjects with non-insulin-dependent diabetes mellitus (NIDDM) accounts for a large part of the excess total mortality of this condition [1, 2]. The increased cardiovascular risk in NIDDM is greater than can be explained by established risk factors such as dyslipidaemia and obesity

R eceived: 7 M ay 1996 and in revised form: 21 A ugust 1996

Corresponding author: L. M cC ormack, U nit of M olecular Vascular M edicine, G - Floor, M artin Wing, The G eneral I nfirmary L eeds, L eeds, LS1 3EX, U K

A bbreviations: NID D M , N on-insulin-dependent diabetes mellitus; PA I-1, plasminogen activator inhibitor-1; CHD, coronary heart disease; PCR, polymerase chain reaction.
[3]. Interest has therefore focused on other features of NIDDM, that may contribute to the elevated vascular risk in subjects with NIDDM , including abnormalities of the coagulation and fibrinolytic cascades. The elevated circulating levels of the fibrinolytic inhibitor plasminogen activator inhibitor-1 (PAI-1) seen in NIDDM [4-8] offer two possible pathways by which vascular damage could occur and lead to the high prevalence of macrovascular disease. First, through impaired fibrinolysis contributing to the formation of atherosclerotic plaques, of which fibrin is an important constituent [9]; second, impaired fibrinolysis may result in a pro-thrombotic state predisposing to formation of thrombi and arterial occlusion. 
There is evidence that genetic factors may be important in determining PA I-1 levels [10-13]. A common insertion/deletion polymorphism has been reported in the promoter region of the PA I-1 gene that has been shown to be related to PAI-1 activity in some populations [11-14]. Environmentally influenced factors, such as serum triglyceride concentrations, have been reported to interact with the PA I-1 genotype to regulate plasma PA I-1 levels in some populations $[10,12,15]$.

The Pima Indians of the G ila River Indian Community in A rizona have the world's highest reported prevalence of NIDDM [16-19]. Despite this, coronary heart disease (CHD) is less common [17, 19-21] with a rate of fatal CHD of half that in diabetic subjects from the Framingham study when controlled for age and sex [19]. A study of the effect of diabetes on PA I-1 levels in three different racial groups found PA I-1 activity levels in diet-treated diabetic Pima Indians were similar to non-diabetic Pima Indians and that levels in these non-diabetic Pima Indians did not differ significantly from non-diabetic Caucasian and $A$ sian subjects [22]. This finding prompted us to investigate the relationship between features of the insulin resistance syndrome and PA I-1 activity levels and the genetic regulation of PA I-1 in Pima Indians. Genotype at a single base-pair insertion/deletion polymorphism was identified and the relationship between levels of PAI-1 and those of other metabolic variables by genotype was investigated in a multiple regression model. Genotype data was obtained on all subjects in the earlier study but insulin-treated subjects were excluded from this study to enable comparison with studies of this polymorphism in other ethnic groups. The low prevalence of CHD and the lack of association between PA I-1 levels and NIDDM in the Pima Indians have yet to be explained and could be due to environmental or genetic factors.

\section{Subjects and methods}

Subject recruitment. Subjects were randomly recruited as part of a longitudinal epidemiological study [17] of N ID D M among the Pima Indian residents of the G ila R iver Indian Community between N ovember 1991 an $O$ ctober 1992. E very 2 years residents of the community over the age of 5 years are asked to undergo a research examination which includes the determination of venous glucose concentration $2 \mathrm{~h}$ after the ingestion of $75 \mathrm{~g}$ of glucose. The diagnosis of diabetes was made by World $\mathrm{H}$ ealth Organisation criteria [23] (plasma glucose $\geq 11.1 \mathrm{mmol} / \mathrm{l} 120 \mathrm{~min}$ after $75 \mathrm{~g}$ carbohydrate load). A ll subjects aged between 35 and 70 years, attending between N ovember 1991 and O ctober 1992, were included unless excluded by the following criteria; pregnancy, a clinical history of ischaemic heart disease, use of thiazide diuretics, oral contraceptives or insulin treatment. H eight and weight were recorded in subjects wearing light clothing without shoes. body mass index was calculated from the subject's weight in kilograms divided by the square of the height measured in meters.
Plasma glucose was measured by a hexokinase method (Ciba-Corning EXPRESS 550 analyser, Ciba-Corning, Norwood $M$ assachusetts). Total serum cholesterol and serum triglycerides were measured by enzymatic methods using a $\mathrm{H}$ itachi 717 analyser (Boehringer Mannheim Indianapolis, Indiana).

Plasma insulin was measured using previously characterised antibodies [24] in a modified two-site microplate immunoenzymometric assay [25]. The assay was sensitive to $2.0 \mathrm{pmol} / \mathrm{l}$ with an intra-assay coefficient of variation of $8.7 \%$ for concentrations above $15 \mathrm{pmol} / \mathrm{l}$ and inter-assay coefficient of variation of $12 \%$.

B lood was collected into EDTA before lysing of the erythrocytes and pelleting of the leukocytes for later D NA extraction. A fter digestion with proteinase K, DNA was extracted by a standard phenol-chloroform method.

D etermination of PA I-1 genotype. PA I-1 4G /5G promoter genotype was established for each subject by polymerase chain reaction (PCR) amplification of genomic DNA using the allele specific primers [26]: insertion $5 \mathrm{G}$ allele; $5^{\prime}-\mathrm{GTC}$ TGG A CA CGT GGG GG-3', deletion 4G allele; 5'-GTC TGG ACA CGT GGG GA-3' each in a separate $P C R$ reaction together with the common downstream primer $5^{\prime}-\mathrm{TGC} A \mathrm{AGC}$ CA G CCA CGT GA T TG T CTA G-3' and a control upstream primer 5'-A A G CTT TTA CCA TGG TAA CCC CTG GT-3' to verify the occurrence of $D N A$ amplification in the absence of the allele on the genomic DNA. The PCR was carried out in a final volume of $25 \mu$ containing $100 \mathrm{ng}$ D NA, $50 \mathrm{pmol}$ of specific and downstream primers, 3 pmol of upstream primers, $0.2 \mu \mathrm{mol} / / \mathrm{dNTPs}$, and $1 \mathrm{U}$ Taq polymerase (G ibco, Paisley, UK). The PCR cycle conditions were $94^{\circ} \mathrm{C}$ for $60 \mathrm{~s}, 65^{\circ} \mathrm{C}$ for $45 \mathrm{~s}$ then $72^{\circ} \mathrm{C}$ for $75 \mathrm{~s}$ for 30 cycles. The amplified D N A fragments were separated by agarose gel electrophoresis and, after staining with ethidium bromide, viewed under ultraviolet light. $E$ ach subject was classified by two observers into one of the three possible genotype groups: $4 G / 4 G, 4 G / 5 G$ or $5 G / 5 G$. To validate this method control subjects of each genotype, as shown by direct sequencing, were run with each batch of samples.

M easurement of PA I-1 activity. A II samples were taken after an overnight fast, between 08.00 and 10.00 hours to minimise the effect of diurnal variation. Blood for PA I-1 activity was collected without venous stasis with a wide-bore needle into prechilled tubes containing 3.8\% sodium citrate solution. Samples were cold centrifuged immediately and the plasma stored at $70^{\circ} \mathrm{C}$. PA I-1 activity was measured by a kit chromogenic substrate method (K abi Vitrum, U xbridge, M iddlesex, UK ), modified to a microplate method. Results are expressed as arbitrary units $(A U / \mathrm{ml})$, one unit of inhibitor being defined as the amount that inhibits one international unit of tissue plasminogen activator. The intra-assay coefficient of variation is $4.5 \%$ and inter-assay coefficient of variation is $8.5 \%$ and detection limit of the assay is $5 \mathrm{~A} \mathrm{U} / \mathrm{ml}$.

\section{Statistical analysis}

Variables with a $\log _{\mathrm{e}}$-normal distribution, insulin, triglycerides, cholesterol and blood glucose, were $\log _{\mathrm{e}}$ transformed and are shown as the geometric mean with its $95 \%$ confidence interval. 0 ther data are presented as arithmetic mean and $95 \%$ confidence interval. Continuous variables were compared using the Student's t-test for independent samples. Categorical variables were compared using the chi-square test. Pearson 
correlation coefficients between the metabolic parameters and PA I-1 levels were calculated.

O ne-way A NOVA was used to compare values between more than two groups of subjects. The relationship of various independent variables to PA I-1 activity levels was assessed by stepwise multiple linear regression analysis with entry criterion as $p<0.05$ and removal criterion as $p>0.1$ for each independent variable.

Two techniques were used to detect the influence of genotype on PA I-1 activity. First, genotype, expressed as two indicator variables was entered in a regression analysis model. Second, the PA I-1 activity data was adjusted for the influence of factors that showed significant correlation with PA I-1 activity, i. e. In insulin and age, and then adjusted levels were compared in the three genotype groups.

The regression slope for the relationship between each metabolic factor (insulin, body mass index, triglyceride, glucose) and PA I-1 was calculated for each genotype and the slopes compared using the method described by A rmitage and B erry [27].

Results

Clinical data. The clinical characteristics of the 265 Pima Indians are shown in Table 1 . Subjects with diabetes had higher fasting glucose, $\mathrm{H} \mathrm{bA}_{1 \mathrm{c}}$ and were older. There was no significant difference in the body mass index of the two groups.

Fibrinolytic data. PA I-1 activity levels and Pearson correlation coefficients between the metabolic parameters and PA I-1 levels have been reported previously for 213 of these subjects [22]. A s there was no difference between the PA I-1 activity levels in the diabetic and non-diabetic subjects (Table 1) these groups were combined to look at the effects of metabolic and genetic variables on PA I-1 activity. In the 265 Pima Indians studied PA I-1 activity correlated with plasma insulin $(r=0.38, p<0.0001)$, body mass index $(r=0.24, p<0.0001)$, and weakly with triglycerides $(r=0.12, p=0.054)$. There was also a negative correlation between age and PAI-1 activity $(r=-0.16, p<0.010)$ and no significant correlation with glucose, cholesterol or $\mathrm{H} \mathrm{bA}_{1 \mathrm{c}}$.

To determine the independent predictors of PA I-1, linear multiple regression analysis was performed with PAI-1 activity as the dependent variable and body mass index, age, sex, insulin, triglycerides, glucose, cholesterol and genotype as the initial independent variables in a stepwise model. A ge and insulin remained in the model as the only independent and significant predictors of PA I-1 activity according to the mathematical expression:

PAI-1 activity $=4.95$ In insulin -0.16 age +2.96 ( $F=25.8, p<0.00001)$

This model accounts for $16.5 \%$ of the variance in PA I-1 levels between individuals.

G enotype data. There were 61 subjects with the $4 \mathrm{G} /$ $4 G$ genotype, 134 with $4 \mathrm{G} / 5 \mathrm{G}$ and 72 with $5 \mathrm{G} / 5 \mathrm{G}$.
Table 1. Subjects characteristics

\begin{tabular}{|c|c|c|c|}
\hline & Diabetic & Non-diabetic & $p$ value \\
\hline Number & 133 & 132 & NS \\
\hline Male : Female & $65: 68$ & $64: 68$ & NS \\
\hline $\begin{array}{l}\text { A ge } \\
\text { (years) }\end{array}$ & $\begin{array}{l}48.7 \\
(47.2-50.2)\end{array}$ & $\begin{array}{l}44.5 \\
(43.2-45.9)\end{array}$ & 0.03 \\
\hline $\begin{array}{l}\text { Body mass index } \\
\left(\mathrm{kg} / \mathrm{m}^{2}\right)\end{array}$ & $\begin{array}{l}33.2 \\
(32.0-34.3)\end{array}$ & $\begin{array}{l}35.7 \\
(34.3-37.1)\end{array}$ & 0.07 \\
\hline $\begin{array}{l}\text { PA I-1 activity } \\
(\mathrm{A} \cup / \mathrm{ml})\end{array}$ & $\begin{array}{l}18.7 \\
(17.1-20.3)\end{array}$ & $\begin{array}{l}18.6 \\
(17.1-20.1)\end{array}$ & NS \\
\hline $\begin{array}{l}\mathrm{HbA}_{1 \mathrm{c}} \\
(\%)\end{array}$ & $\begin{array}{l}8.7 \\
(8.3-9.0)\end{array}$ & $\begin{array}{l}5.5 \\
(5.4-5.6)\end{array}$ & $<0.0001$ \\
\hline Fasting glucose $(\mathrm{mmol} / \mathrm{l})$ & $\begin{array}{l}9.8 \\
(9.1-10.5)\end{array}$ & $\begin{array}{l}5.4 \\
(5.4-5.5)\end{array}$ & $<0.0001$ \\
\hline Cholesterol ${ }^{\mathrm{a}}(\mathrm{mmol} / \mathrm{l})$ & $\begin{array}{l}4.42 \\
(4.27-4.58)\end{array}$ & $\begin{array}{l}4.36 \\
(4.22-4.49)\end{array}$ & NS \\
\hline Triglycerides ${ }^{\mathrm{a}}(\mathrm{mmol} / \mathrm{l})$ & $\begin{array}{l}1.49 \\
(1.35-1.65)\end{array}$ & $\begin{array}{l}1.29 \\
(1.18-1.42)\end{array}$ & NS \\
\hline $\begin{array}{l}\text { Insulina } \\
\text { (pmol/l) }\end{array}$ & $\begin{array}{l}105.7 \\
(93.6-119.3)\end{array}$ & $\begin{array}{l}104.7 \\
(93.4-117.4)\end{array}$ & NS \\
\hline $\begin{array}{l}\text { Treatment } \\
\text { (D iet: Sulphonylurea) }\end{array}$ & $74: 59$ & & \\
\hline
\end{tabular}

Data shown as the geometric mean ( $95 \%$ confidence interval) or where log transformed as geometric mean and anti-logged ( $95 \%$ confidence interval). Parameters were compared using the t-test for independent samples or chi-square test where appropriate

The genotype frequencies were not different from those predicted by $\mathrm{H}$ ardy-Weinberg equilibrium. The allele frequencies were 0.48 and 0.52 for $4 \mathrm{G}$ and $5 G$, respectively (Table 2 ). There was no difference in the genotype distribution between diabetic and non-diabetic Pima Indians ( $\chi^{2}=1.94,2 \mathrm{df}, \mathrm{p}=0.38$ ). The genotype frequencies in the Pima Indians were however significantly different from those observed in a previously reported study of 189 Caucasian subjects with NIDD M in L eeds, UK [15] ( $\chi^{2}=15.2,2 \mathrm{df}$, $p<0.0005$ ) (Fig. 1). There was no relationship between PAI-1 genotype and PAI-1 concentrations alone or when adjusted for features of the insulin resistance syndrome (Table 2). Power calculations estimate this study had an $80 \%$ likelihood of detecting a difference in PA I-1 activity of $4.5 \mathrm{mU} / /$ between the $4 G / 4 G$ and $5 G / 5 G$ groups at the $p<0.05$ level. This would represent a $25 \%$ difference between the highest level of $19 \mathrm{mU} / \mathrm{l}$ and the lowest levels, a difference less than was detected between $4 \mathrm{G} / 4 \mathrm{G}$ subjects and $5 G / 5 G$ subjects in NID D M subjects in the U K [12].

G ene-environment interactions. Table 3 shows the results of the regression analyses. There was no difference in the regression slopes of PAI-1 on triglycerides, insulin or glucose between genotype groups. For PA I-1 on body mass index the regression slope in the $4 G / 4 G$ group was significantly steeper than in the $4 G / 5 G$ group $(p=0.022)$, although no adjustment has been made for multiple comparisons. 
Table 2. R elationship between genotype and PA I-1 activity levels

\begin{tabular}{|c|c|c|c|c|}
\hline & \multicolumn{4}{|c|}{ PA I-1 genotype } \\
\hline & $4 \mathrm{G} / 4 \mathrm{G}$ & $4 \mathrm{G} / 5 \mathrm{G}$ & $5 G / 5 G$ & A\| \\
\hline $\begin{array}{l}N \text { umber of subjects } \\
\text { D iabetic: non-diabetic }\end{array}$ & $\begin{array}{l}61 \\
26: 35\end{array}$ & $\begin{array}{l}132 \\
68: 64\end{array}$ & $\begin{array}{l}72 \\
39: 33\end{array}$ & $\begin{array}{l}265 \\
133: 132\end{array}$ \\
\hline PA I-1 activity ( $\mathrm{A} \cup / \mathrm{ml})$ & $\begin{array}{l}18.2 \\
(15.9-20.5)\end{array}$ & $\begin{array}{l}19.1 \\
(17.5-20.7)\end{array}$ & $\begin{array}{l}18.1 \\
(16.0-20.2)\end{array}$ & $\begin{array}{l}18.6 \\
(17.5-19.7)\end{array}$ \\
\hline A djusted PA I-1 activity ${ }^{a}$ & $\begin{array}{l}18.1 \\
(15.9-20.2)\end{array}$ & $\begin{array}{l}19.0 \\
(17.6-20.5)\end{array}$ & $\begin{array}{l}18.3 \\
(16.5-20.2)\end{array}$ & $\begin{array}{l}18.6 \\
(17.6-19.6)\end{array}$ \\
\hline PA I-1 activity $(\mathrm{A} U / \mathrm{ml})$ in diabetic subjects & $\begin{array}{l}18.0 \\
(13.9-22.0)\end{array}$ & $\begin{array}{l}19.1 \\
(16.8-21.4)\end{array}$ & $\begin{array}{l}18.4 \\
(15.3-21.4)\end{array}$ & $\begin{array}{l}18.7 \\
(17.1-20.3)\end{array}$ \\
\hline PA I-1 activity $(A \cup / m l)$ in non-diabetic subjects & $\begin{array}{l}18.4 \\
(15.6-21.2)\end{array}$ & $\begin{array}{l}19.1 \\
(16.8-21.4)\end{array}$ & $\begin{array}{l}17.7 \\
(14.7-20.6)\end{array}$ & $\begin{array}{l}18.6 \\
(17.1-20.1)\end{array}$ \\
\hline
\end{tabular}

a PA I-1 activity ( $\mathrm{U} / \mathrm{ml})$ adjusted for insulin and age in a multiple regression model, shown as mean and (95\% confidence interval)

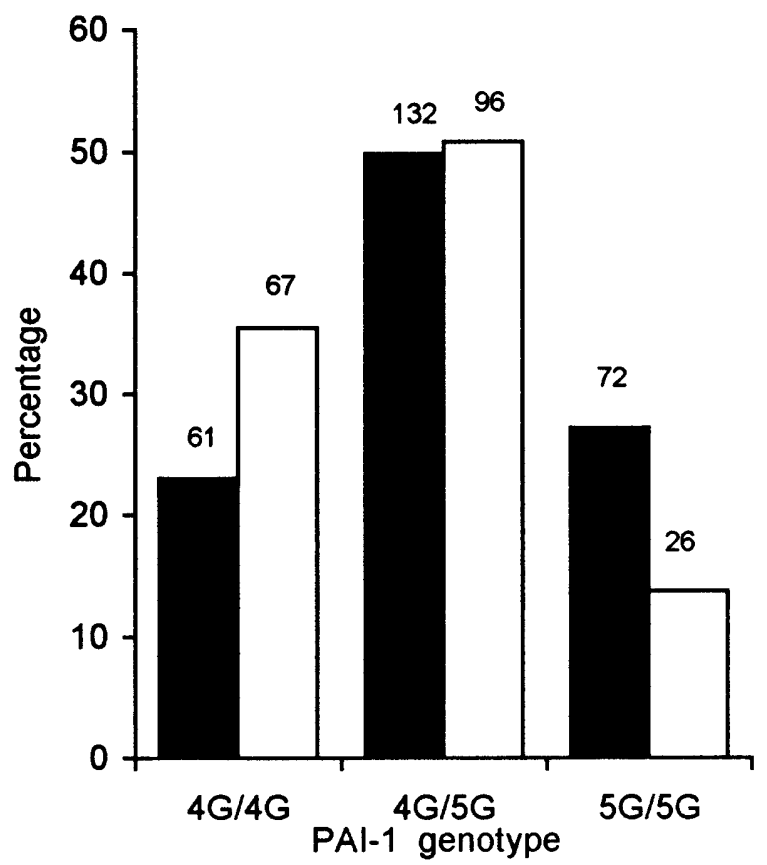

Fig. 1. The frequency of each genotype in Pima Indians ( $\square$ ) compared to Caucasian subjects $(\square)$ with NIDDM in Leeds. $\left(\chi^{2}=15.2,2 d f, p<0.0005\right)$. The number of individuals is shown above each bar

\section{Discussion}

Elevated circulating levels of PA I-1 seen in Caucasian subjects with NIDDM [4-8] may contribute to vascular damage and hence to the high prevalence of macrovascular disease in this disorder. Evidence to support this view comes from studies in which elevated levels of PAI-1 predict recurrent infarction in a group of young survivors of myocardial infarction $[28,29]$ and may predict poor outcome from myocardial infarction [30].

The causes of high levels of PA I-1 seen in Caucasians in NID D M remain to be established. Insulin resistance and its associated features have all been implicated in this process. Insulin resistance has a strong correlation with PA I-1 levels in glucose-clamp studies in hypertensive [31], obese [32], and subjects with NIDDM [33]. This relationship has also been found in population studies where insulin resistance is identified indirectly by the presence of its associated features [8, 28, 29, 31, 33-38].

It is difficult to distinguish the effects of insulin resistance from those of hyperinsulinaemia, hypertriglyceridaemia, male pattern obesity, high BMI, systolic hypertension, low H D L-cholesterol and glucose intolerance. I $n$ vitro cell stimulation experiments provide evidence to implicate insulin [39-41] very low density lipoproteins from hypertriglyceridaemic subjects [42] and high glucose levels [43-44] in the production of elevated PAI-1 levels. However, in vivo studies have failed to demonstrate an effect of hyperinsulinaemia [45-48] or hypertriglyceridaemia [45] on PA I-1 levels. While some studies find a significant correlation between PA I-1 and glycaemia [12], others have shown only a weak correlation $[15,49,50]$.

$E$ vidence that genetic factors are important in determining PA I-1 levels comes from clinical studies. Initially, a 3' $\mathrm{H}$ ind III R FL P and an intronic dinucleotide (CA ) repeat were shown to be related to elevated PA I-1 levels [10]. M ore recently, an insertion/ deletion (4G/5G) polymorphism has been related to circulating levels of PA I-1 in several large studies of NIDDM and non-diabetic subjects. L evels are highest in subjects with the 4G /4G genotype and generally about one-third higher than subjects homozygous for the 5G allele [11-13]. R ecent studies have shown an association between genotype at this site and coronary artery disease itself $[13,51]$. Evidence that the informative nature of the $4 \mathrm{G} / 5 \mathrm{G}$ polymorphism lies in it being a functional site comes from in vitro studies demonstrating differential enhancer/repressor binding at the $4 G$ and $5 G$ sites $[11,13]$. Studies of gene-environment interactions in patients have provided further information on the functional nature of the $4 G / 5 G$ mutation, with three studies having 
Table 3. R egression slopes for PA I-1 activity on the metabolic variables for the different PA I-1 genotypes

\begin{tabular}{lllrll}
\hline & Genotype $^{\mathrm{a}}$ & $\mathrm{R}$ & slope & SE slope & $\mathrm{p}$-value \\
\hline In Insulin & $4 \mathrm{G} / 4 \mathrm{G}$ & 0.44 & 5.77 & 1.51 & 0.0003 \\
& $4 \mathrm{G} / 5 \mathrm{G}$ & 0.31 & 4.22 & 1.13 & 0.0003 \\
A ge & $5 \mathrm{G} / 5 \mathrm{G}$ & 0.44 & 5.69 & 1.4 & 0.0001 \\
& $4 \mathrm{G} / 4 \mathrm{G}$ & 0.09 & 0.09 & 0.14 & 0.05 \\
Body mass index & 4G $/ 4 \mathrm{G}$ & 0.42 & 0.61 & 0.17 & 0.001 \\
& 4G $/ 5 \mathrm{G}$ & 0.22 & -0.23 & 0.09 & 0.01 \\
& $4 \mathrm{G} / 5 \mathrm{G}$ & 0.12 & 0.14 & 0.10 & $\mathrm{NS}$ \\
In Triglyceride & $5 \mathrm{G} / 5 \mathrm{G}$ & 0.35 & 0.39 & 0.13 & 0.003 \\
& $4 \mathrm{G} / 4 \mathrm{G}$ & 0.06 & 1.25 & 2.78 & $\mathrm{NS}$ \\
& $4 \mathrm{G} / 5 \mathrm{G}$ & 0.09 & 1.44 & 1.34 & $\mathrm{NS}$ \\
In G lucose & $5 \mathrm{G} / 5 \mathrm{G}$ & 0.19 & 2.93 & 1.85 & $\mathrm{NS}$ \\
& $4 \mathrm{G} / 4 \mathrm{G}$ & 0.02 & 0.42 & 3.28 & $\mathrm{NS}$ \\
& $4 \mathrm{G} / 5 \mathrm{G}$ & 0.07 & -1.44 & 1.84 & $\mathrm{NS}$ \\
& $5 \mathrm{G} / 5 \mathrm{G}$ & 0.21 & 4.74 & 2.67 & $\mathrm{NS}$ \\
\hline
\end{tabular}

${ }^{a}$ Number of subjects $4 G / 4 G=61,4 G / 5 G=132,5 G / 5 G=72$;

b $4 G / 4 G$ genotype $v 4 G / 5 G p=0.022$

demonstrated an interaction between triglycerides and genotype in relation to PA I-1 levels [10, 12, 15].

In contrast to the studies in Caucasians that have not shown a significant difference between PA I-1 levels in the different genotypes [15], in the Pima Indians not even a trend towards higher levels was seen with possession of one or more 4G alleles. Pre-existing vascular disease may be necessary for expression of the genotype effect on PA I-1 levels, and this could explain the absence of an effect of genotype on PA I-1 levels in Pima Indians.

In Pima Indians CHD is infrequent despite the high prevalence of diabetes and obesity. This population, in which the prevalence of CHD is low even in subjects with NIDDM, could give important clues to the factors that form the link between NIDDM and CHD in other populations. In these Pima Indians there was no significant difference between PA I-1 activity levels in diabetic and non-diabetic subjects despite a similar relationship between PAI-1 activity and the features of insulin resistance to that observed in studies of Caucasians.

The prevalence of the different alleles at the $4 \mathrm{G} /$ $5 \mathrm{G}$ locus has mainly been studied previously in Caucasian populations and demonstrate broadly similar prevalences whether patients are derived from Swedish or British populations. In the present study the Pima Indian population was found to have a significantly lower prevalence of the potentially deleterious 4G /4G genotype than in Caucasian subjects. A dditionally, unlike some of the previous studies, there was no relationship between possession of a particular genotype at this locus and circulating levels of PA I-1. This variation in genotype prevalence may merely reflect random ethnic differences of no biological significance, alternatively this may be one of several genes predisposing an individual to $\mathrm{CHD}$ which may account for the lower prevalence of heart disease seen in this ethnic group.

In this group of Pima Indians we found a similar though weaker correlation between PA I-1 and triglyceride levels than previously found in Caucasian subjects with NIDDM. No relationship was found between PAI-1 genotype at the $4 \mathrm{G} / 5 \mathrm{G}$ polymorphic site and the regression slope for PAI-1 activity on triglyceride or glucose concentration. The regression of PA I-1 on body mass index showed a steeper slope in the $4 \mathrm{G} / 4 \mathrm{G}$ group compared to the $4 \mathrm{G} / 5 \mathrm{G}$ group, although this may be a chance finding.

The reason for the absence in this ethnic group of the genotype specific relationship between PA I-1 activity and triglyceride that has been observed in Caucasians is unclear. However, one possibility is that binding of transcription factors differs in Pima Indians leading to alterations in gene regulation compared to $C$ aucasians. $D$ ifferences in triglyceride levels could also be involved. A Ithough the allele frequencies in the Pima Indians were significantly different from those observed in Caucasian populations, it is unlikely that the absence of a relationship between 4G/5G genotype and PA I-1 levels in Pima Indians would be explained solely by differences in genotype frequency suggesting changes in other regulatory functions.

In summary, this study demonstrates that in Pima Indians there is no relationship between the PA I-1 4G/5G polymorphism, PA I-1 levels and most features of the insulin resistance syndrome. H owever, a genotype specific relationship between body mass index and PA I-1, with a steeper slope in the 4 G /4G group was observed. In contrast to most studies in Caucasian subjects, there was no direct relationship between PAI-1 genotype and levels of PAI-1. These data suggest that this polymorphic site is not involved in the regulation of PA I-1 synthesis in Pima Indians. This may indicate a functional difference in the PA I-1 gene in this population. Further studies are required to elucidate the relationship between the PAI-1 gene, circulating PA I-1 levels and the presence of vascular disease in the Pima population.

A cknowledgements. The authors wish to thank the members of the Gila River Indian Community for participating in these studies. D.K. N agi was supported by the B ritish D iabetic A ssociation-I mperial Chemical Industries Transatlantic fellowship.

\section{References}

1. K annel W B, M CG ee D L (1979) D iabetes and cardiovascular disease, the Framingham Study. JA M A 241: 2035-2038

2. M ultiple R isk Factor I ntervention Trial (M R FIT) R esearch Group (1982) Multiple risk factor intervention trial: risk factor changes and mortality results. JAMA 248: 1465- 1477 
3. Pyörälä K (1979) R elationship of glucose tolerance and plasma insulin to the incidence of coronary heart disease. Results from two population studies in Finland. Diabetes Care 2: 131-141

4. Walmsley D, H ampton K K , G rant PJ (1991) Contrasting fibrinolytic responses in type 1 (insulin-dependent) and type 2 (non-insulin-dependent) diabetes. D iabet M ed 8: 954-959

5. A uwerx J, B ouillon R, Collen D, G eboers J (1988) Tissuetype plasminogen activator antigen and plasminogen activator inhibitor in diabetes mellitus. A rteriosclerosis 8: 6872

6. Garcia Frade LJ, de la Calle H, Torrado M C, L ara JI, CuelIar L, Garcia A vello A (1990) H ypofibrinolysis associated with vasculopathy in non insulin dependent diabetes mellitus. Thromb R es 59: 51-59

7. G ough SCL, R ice PJ S, M CC ormack L, Chapman C, G rant PJ (1993) The relationship between plasminogen activator inhibitor-1 and insulin resistance in newly diagnosed type 2 diabetes mellitus. D iabet $M$ ed 10: 638-642

8. Juhan-Vague I, R oul C, A lessi M C, A rdissone J P, H eim M, Vague $P$ (1989) Increased plasminogen activator inhibitor activity in non-insulin-dependent diabetic patients - relationship with plasma insulin. Thromb H aemost 61: 370-373

9. Smith E B (1986) Fibrinogen, fibrin and fibrin degradation products in relation to atherosclerosis. Clin $\mathrm{H}$ aematol 15: 355-370

10. D awson $S, H$ amsten $A$, Wiman $B, H$ enney $A, H$ umphries $S$ (1991) G enetic variation at the plasminogen activator inhibitor-1 locus is associated with altered levels of plasma plasminogen activator inhibitor-1 activity. A rterioscler Thromb 11: 183-190

11. D awson S, Wiman B, Hamsten A, G reen F, H umphries $S$, Henney A (1993) The two allele sequences of a common polymorphism in the promoter of the plasminogen activator inhibitor-1 (PA I-1) gene respond differently to interleukin-1 in H epG 2 cells. J Biol Chem 268: 10739-10745

12. Panahloo A, M ohamed-A li V, Lane A, G reen F, H umphries S, Yudkin J (1995) D eterminants of plasminogen activator inhibitor 1 activity in treated NID D M and its relation to a polymorphism in the plasminogen activator inhibitor 1 gene. Diabetes 44: 37-42

13. E riksson $P$, $K$ allin $B$, van ' $T H$ ooft $F M, B$ åvenholm $P, H$ amsten A (1995) A llele-specific increase in basal transcription of the plasminogen-activator inhibitor 1 gene is associated with myocardial infarction. Proc Natl A cad Sci USA 92: 1851-1855

14. Ye S, G reen FR, Scarabin PY et al. (1995) The $4 G / 5 G$ genetic polymorphism in the promoter region of the plasminogen activator inhibitor-1 (PA I-1) gene is associated with differences in plasma PA I-1 activity but not with risk of myocardial infarction in the ECTIM study. Thromb Haemost 74: 837-841

15. M ansfield M W, Stickland M H, Grant PJ (1995) Environmental and genetic factors in relation to circulating levels of plasminogen activator inhibitor-1 in Caucasian patients with non-insulin-dependent diabetes mellitus. Thromb H aemost 74: 842-847

16. Bennett PH, Rushforth NB, Miller M, LeCompte PM (1976) E pidemiologic studies of diabetes in the Pima Indians. R ecent Prog $\mathrm{H}$ orm $\mathrm{R}$ es 32: 333-376

17. K nowler W C, B ennett PH, H amman RF, M iller M (1978) Diabetes incidence and prevalence in Pima Indians: a 19fold greater incidence than in R ochester, M innesota. A m J E pidemiol 108: 497-505

18. K nowler WC, Pettitt D J, Savage PJ, B ennett PH (1981) D iabetes incidence in Pima Indians: contribution of obesity and parental diabetes. A m J E pidemiol 113: 144-156
19. N elson R G, Sievers M L, K nowler WC et al. (1990) L ow incidence of fatal coronary heart disease in Pima Indians despite high prevalence of non-insulin-dependent diabetes. Circulation 81: 987-995

20. Howard BV, Welty TK, Fabsitz R R et al. (1992) R isk factors for coronary heart disease in diabetic and non-diabetic native A mericans. The Strong Heart Study. Diabetes 41 [Suppl 2]:4-11

21. Sievers M L, N elson R G, B ennett PH (1990) A dverse mortality experience of a southwestern A merican Indian community: overall death rates and underlying causes of death in Pima Indians. J Clin E pidemiol 43: 1231-1242

22. Nagi DK, Knowler WC, Hanson RL, Mohamed A li V, Yudkin J S (1996) Plasminogen activator inhibitor-1 (PA I1) and non-insulin-dependent diabetes in Pima Indians, South A sians and E uropeans: populations at varying risk of N ID D M and coronary artery disease. Thromb H aemost 75: 921-927

23. World Health O rganisation (1985) Diabetes mellitus. R eport of a WHO Study G roup. Technical R eport Series No. 727, W H O, G eneva

24. Sobey WJ, B eer SF, Carrington CA et al. (1989) Sensitive and specific two-site immunoradiometric assays to human insulin, proinsulin, 65-66 split and 32-33 split proinsulin. Biochem J 260: 535-541

25. M ohamed-A li V, Y udkin J S (1992) A n end-point amplified immunoenzymometric assay (IEMA) specific for human insulin. Clin Sci 82:[Suppl 27] 4P (A bstract)

26. Falk G, A Imqvist A, N ordenhem A, Svensson H, Wiman B (1995) Allele specific PCR for detection of a sequence polymorphism in the promoter region of the plasminogen activator inhibitor-1 (PA I-1) gene. Fibrinolysis 9: 170-174

27. A rmitage $P, B$ erry $G$ (1987) Statistical methods in medical research. 2nd edn B lackwell, Oxford, U K, pp 273-282

28. H amsten A, Wiman B, de Faire U, B lombäck M (1985) Increased plasma levels of a rapid inhibitor of tissue plasminogen activator in young survivors of myocardial infarction. N Engl J Med 313: 1557-1563

29. H amsten A, de Faire U, Walldius G et al. (1987) Plasminogen activator inhibitor in plasma: risk factor for recurrent myocardial infarction. L ancet 2: 3-9

30. Gray R P, Y udkin J S, Patterson D L (1993) Enzymatic evidence of impaired reperfusion in diabetic patients after thrombolytic therapy for acute myocardial infarction - A role for plasminogen activator inhibitor? $\mathrm{Br} \mathrm{H}$ eart J 70 : 530-536

31. L andin K, Tengborn L, Smith U (1990) E levated fibrinogen and plasminogen activator inhibitors (PA I-1) in hypertension are related to metabolic risk factors for cardiovascular disease. J Int M ed 227: 273-278

32. L andin K, Stigendal L, E riksson E et al. (1990) A bdominal obesity is associated with an impaired fibrinolytic activity and elevated plasminogen activator inhibitor-1. M etabolism 39: 1044-1048

33. Potter van Loon BJ, Kluft K, Radder JK, Blankenstein M A, M einders A E (1993) The cardiovascular risk factor plasminogen activator inhibitor-1 is related to insulin resistance. M etabolism 42: 945-949

34. Vague P, Juhan-Vague I, A illaud M F et al. (1986) Correlation between blood fibrinolytic activity, plasminogen activator inhibitor level, plasma insulin level, and relative body weight in normal and obese subjects. M etabolism 35 : 250-253

35. J uhan-Vague I, A lessi M C, J oly P et al. (1989) Plasma plasminogen activator inhibitor-1 in angina pectoris. Influence of plasma insulin and acute phase-response. A rteriosclerosis 9: 362-367 
36. Sundell IB, Nilsson TK, H allmans G, H ellsten G, Dahlen $\mathrm{GH}$ (1989) Interrelationships between plasma levels of plasminogen activator inhibitor, tissue plasminogen activator, lipoprotein(a), and established cardiovascular risk factors in a North Swedish population. A therosclerosis 80: 916

37. M ussoni L, Mannucci L, Sirtori M et al. (1992) Hypertriglyceridaemia and regulation of fibrinolytic activity. A rterioscler Thromb 12: 19-27

38. M ehta J, M ehta P, L awson D, Saldeen T (1987) Plasma tissue plasminogen activator inhibitor levels in coronary artery disease: correlations with age and triglyceride concentrations. J A m Coll Cardiol 9: 263-268

39. A lessi M C, Juhan-Vague I, K ooistra T, D eclerk PJ, Collen D (1988) Insulin stimulates the synthesis of plasminogen activator-1 by hepatocellular cell line Hep G2. Thromb $\mathrm{H}$ aemost 60: 491-494

40. Kooistra T, B osma PJ, Tons H A M , van den B erg A P, M eyer P, Princen HMG (1989) Plasminogen activator inhibitor 1: biosynthesis and mRNA level are increased in Hep G2 cells. Thromb H aemost 62: 723-728

41. G rant PJ, R üegg M , M edcalf RL (1991) B asal expression and insulin-mediated induction of PA I-1 mRNA in Hep G 2 cells. Fibrinolysis 5: 81-86

42. Stiko-R ahm A , Wiman B, H amsten A , Nilsson J (1990) Secretion of plasminogen activator inhibitor-1 from cultured human umbilical vein endothelial cells is induced by very low density lipoprotein. A rteriosclerosis 10: 1067-1073

43. M aiello M, Boeri D, Podesta F et al. (1992) Increased expression of tissue plasminogen activator and its inhibitor and reduced fibrinolytic potential of human endothelial cells cultured in elevated glucose. D iabetes 41: 1009-1015

44. N ordt TK, K lassen K J, Schneider DJ, Sobel BE (1993) A ugmentation of synthesis of plasminogen activator inhibitor type- 1 in arterial endothelial cells by glucose and its implications for local fibrinolysis. A rterioscler Thromb 13: 1822-1828

45. G rant PJ, K ruithof E K O, Felley CP, Felber J P, B achmann F (1990) Short term infusions of insulin, triacylglycerol and glucose do not cause acute increases in plasminogen activator inhibitor-1 concentrations in man. Clin Sci 79: 513-516

46. Potter van Loon BJ, deB art A CW, Radder J K, Frölich $M$, K luft C, M einders A E (1990) A cute exogenous hyperinsulinaemia does not result in elevation of plasminogen activator inhibitor-1 (PAI-1) in humans. Fibrinolysis 4 [Suppl 2]:93-94

47. L andin K, Tengborn L, Chmielewska J, von Schenck $H$, Smith U (1991) The acute effect of insulin on tissue plasminogen activator and plasminogen activator inhibitor in man. Thromb H aemost 65: 130-133

48. M cC ormack L, Stickland M H, G rant PJ (1993) Plasminogen activator inhibitor-1 antigen concentrations during insulin and oral glucose tolerance tests in obese man. Fibrinolysis 7: 225-228

49. G unnarsson R, Nyman D, Wålinder O, Östman J (1980) Fibrinolytic activity and diabetes control - evidence for a relationship. A preliminary report. A cta Med Scand [Suppl] 639: 23-24

50. van Wersch JWJ, Donders SHJ, Westerhuis LWJJM, Venekamp WJR R (1991) M icroalbuminuria in diabetic patients: relationship to lipid glyco-metabolic, coagulation and fibrinolysis parameters. E ur J Clin Chem Clin Biochem 29: 493-498

51. M ansfield M W, Stickland M H, Grant PJ (1995) Plasminogen activator inhibitor-1 (PA I-1) promoter polymorphism and coronary artery disease in non insulin dependent diabetes. Thromb H aemost 74: 1032-1034 